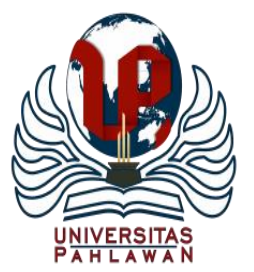

\author{
JURNAL BASICEDU \\ Research \& Learning in Elementary Education \\ https://jbasic.org/index.php/basicedu/index
}

Jurnal Basicedu Volume 4 Nomor 4 Tahun 2020 Halm. 977 - 984

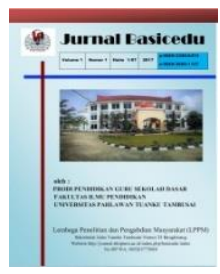

\title{
Pengembangan Desain Pembelajaran Model ASSURE Menggunakan VAK Di Sekolah Dasar
}

\author{
Hendra Noviandi ${ }^{1}$, Neviyarni $S^{2}$, Farida $F^{3}$ \\ Universitas Negeri Padang, Sumatera Barat, Indoesia ${ }^{1,2,3}$ \\ E-mail : $\underline{\text { hendranoviandi88@gmail.com }}$ neviyarni@ $\underline{\text { konselor.org }} \underline{\text { faridafachrudin6@ gmail.com }}^{3}$
}

\begin{abstract}
Abstrak
Penelitian ini bertujuan menghasilkan desain pembelajaran model ASSURE menggunakan VAK pada pembelajaran tematik terpadu tema 9 kelas IV SD yang valid, praktis, dan efektif. Desain pembelajaran yang dikembangkan berupa RPP (Rencana Pelaksanaan Pembelajaran). Jenis penelitian ini adalah penelitian pengembangan dengan model ASSURE menggunakan VAK. Subjek penelitian peserta didik kelas IV SD Negeri 16 Gadut. Data dikumpulkan menggunakan lembar pengamatan keterlaksanaan desain pembelajaran, angket respon peserta didik, angket respon pendidik, aktivitas peserta didik selama proses pembelajaran dan hasil belajar. Data yang diperoleh selanjutnya diolah dan dianalisis secara deskriptif. Hasil penelitian menunjukkan bahwa desain pembelajaran yang dikembangkan berada pada kategori sangat valid. Berdasarkan hasil uji coba yang dilakukan, diperoleh bahwa desain pembelajaran memenuhi aspek kepraktisan ditinjau dari respon pendidik dan peserta didik. Desain pembelajaran ini juga memenuhi aspek keefektifan yang dilihat dari : 1) aktivitas peserta didik; 2) sikap;3) pengetahuan peserta didik yang diharapkan melampaui KBM (Ketuntasan Belajar Minimal) ; 4) keterampilan peserta didik. Desain pembelajaran yang dikembangkan berupa RPP memiliki karakteristik: 1) praktis dalam penggunaan dan 2) menggunakan bahasa yang jelas, logis, dan sistematis.
\end{abstract}

Kata kunci: desain pembelajaran, model ASSURE, VAK, pembelajaran tematik terpadu

\section{Abstract}

This study aims to produce ASSURE model of learning design with VAK on integrated thematic learning theme 9 grade IV elementary school that is valid, practical, and effective. Learning design developed in the form of RPP (Learning Implementation Plan). This type of research is development research with the ASSURE model with VAK. Data was collected using observations sheet of the implementation of learning design, student response questionnaire, educator response questionnaire, student activities during the learning process and learning outcomes. The data obtained are then processed and analyzed descriptively. It is hoped that the research results show that the learning design developed is in the very valid category. Based on the results of the trials that will be conducted, it is found that the learning design is expected to meet practical aspects in terms of the response of educators and students. This learning design is also expected to meet the effectiveness aspects seen from: 1) learners' activities; 2) attitude; 3) students' knowledge that is expected to exceed KBM; 4) student skills. The learning design developed in the form of lesson plans has the following characteristics: 1) practical in use and 2) using clear, logical, and systematic language.

Keywords: learning design, ASSURE model, VAK, integrated thematic learning

Copyright $\odot 2020$ Hendra Noviandi, Neviyarni, Farida F

$\triangle$ Corresponding author :

Address : Air Tawar Padang

Email : hendranoviandi88@gmail.com

Phone : 089531307164

ISSN 2580-3735 (Media Cetak)

ISSN 2580-1147 (Media Online)

DOI : https://doi.org/10.31004/basicedu.v4i4.491 


\section{PENDAHULUAN}

Salah satu dimensi yang tidak bisa dipisahkan dari pembangunan dunia pendidikan nasional di masa depan adalah kebijakan mengenai kurikulum. Kurikulum merupakan jantungnya dunia pendidikan. Untuk itu, kurikulum di masa depan perlu dirancang dan disempurnakan untuk meningkatkan mutu pendidikan secara nasional dan meningkatkan mutu sumber daya manusia Indonesia (Permendikbud, 2013).

Sejak zaman Indonesia merdeka, kurikulum sudah mengalami 11 kali perubahan. Terakhir kurikulum berubah dari kurikulum KTSP menjadi Kurikulum 2013 (Trianto, 2014). Idealnya perubahan kurikulum direncanakan secara matang. Hal-hal yang perlu dilakukan dalam perubahan kurikulum misalnya: evaluasi menyeluruh terhadap kurikulum lama, analisis kebutuhan terhadap tantangan zaman, penyusunan perangkat kurikulum, dan sosialisasi secara optimal (Alimuddin, 2014).

Penyelenggaraan pendidikan pada jenjang sekolah dasar bertujuan memberikan bekal kepada peserta didik untuk hidup bermasyarakat dan dapat melanjutkan pendidikan ke jenjang yang lebih tinggi. Seorang peserta didik yang mendapatkan layanan pendidikan di Sekolah Dasar (SD) dengan benar dan baik, maka peserta didik tersebut akan lebih besar peluang sukses pada jenjang pendidikan berikutnya. Menindaklanjuti kurikulum SD sebelumnya (KTSP), yang sekarang ini lebih disempurnakan ke dalam kurikulum 2013 (Joseph, 2017). Kurikulum 2013 pada dasarnya merupakan upaya penyederhanaan dan tematik-integratif yang disiapkan untuk mencetak generasi yang siap di dalam menghadapi masa depan. Karena itu, kurikulum disusun untuk mengantisipasi perkembangan masa depan. Titik beratnya, bertujuan untuk mendorong peserta didik atau siswa, mampu lebih baik dalam melakukan keterampilan proses (Noviati, Bentri, \& Zikri, 2020).

Pembelajaran tematik terpadu merupakan pembelajaran yang mengintegrasikan berbagai kompetensi dari berbagai mata pelajaran ke dalam berbagai tema sehingga pembelajaran tersebut dapat memberikan pengalaman bermakna kepada peserta didik. Di samping itu, pembelajaran tematik terpadu memberikan pengalaman belajar yang menyenangkan karena relevan dengan kehidupan peserta didik. Pembelajaran tematik terpadu adalah kegiatan pembelajaran menciptakan rasa nyaman dan aman kepada peserta didik, dalam proses pembelajarannya bersifat individual dan kontekstual sehingga anak mengalami langsung apa yang dipelajarinya" (Kemendikbud, 2013).

Pembelajaran tematik terpadu merupakan suatu pendekatan dalam pembelajaran yang secara sengaja mengaitkan beberapa aspek baik dalam intra mata pelajaran maupun antar mata pelajaran. Dengan adanya pemaduan itu, peserta didik akan memperoleh pengetahuan dan keterampilan secara utuh sehingga pembelajaran menjadi bermakna bagi peserta didik. Makna pembelajaran tematik terpadu adalah pendekatan pembelajaran yang melibatkan beberapa mata pelajaran untuk memberikan pengalaman yang bermakna kepada peserta didik. Dikatakan bermakna pada pembelajaran Tematik Terpadu artinya, peserta 
didik akan memahami konsep-konsep yang mereka pelajari melalui pengalaman langsung dan menghubungkan dengan konsep yang lain yang sudah mereka pahami (Marta, Fitria, Hadiyanto, \& Zikri, 2020)

Karakteristik pembelajaran tematik berpusat pada peserta didik, pemisahan antar mata pelajaran tidak tampak, menyajikan konsep dari berbagai mata pelajaran, fleksibel, hasil pembelajaran berkembang sesuai dengan minat dan kebutuhan peserta didik. Kemendikbud (2013) memberikan konsepsi bahwa pendekatan ilmiah (scientific approach) dalam pembelajaran mencakup komponen: mengamati, menanya, mencoba, mengolah, menyajikan, menyimpulkan, dan mencipta (Kemendikbud, 2014).

Kurikulum 2013 SD/MI menggunakan pendekatan pembelajaran tematik dari kelas I sampai kelas VI, Pembelajaran tematik merupakan pendekatan pembelajaran yang mengintegrasikan berbagai kompetensi dari berbagai mata pelajaran ke dalam berbagai tema. Tema merupakan alat atau wadah untuk mengenalkan berbagai konsep kepada peserta didik secara utuh. Dalam pembelajaran, tema diberikan dengan maksud menyatukan isi kurikulum dalam satu kesatuan yang utuh, memperkaya perbendaharaan bahasa peserta didik dan membuat pelajaran lebih bermakna (Karli, 2016).

Persoalan yang mungkin muncul adalah bagaimana menggabungkan beberapa muatan pelajaran dalam satu subtema yang temanya telah ditetapkan dengan kompetensi yang berbeda antar muatan pelajaran. Satu Rencana Pelaksanaan Pembelajaran dilaksanakan dalam satu pertemuan untuk satu hari, karena dalam penerapan kurikulum 2013 telah ditentukan bahwa satu pembelajaran terdiri dari 2-3 muatan pelajaran yang akan diajarkan, sementara kompetensi dari muatan pelajaran itu berbeda. Oleh sebab itu perlu diciptakan desain pembelajaran untuk menggabungkan muatan pelajaran dalam satu subtema sehingga menciptakan desain pembelajaran yang valid, praktis, dan efektif.

Pada proses pelaksanaan pendidikan di sekolah, guru mempunyai peranan penting dan utama dalam membimbing anak agar mencapai tujuan yang diharapkan. Metode dan keputusan guru dalam proses pembelajaran sangat menentukan keberhasilan anak didiknya. Secara sederhana desain pembelajaran adalah suatu rancangan yang sistematis dan sistemik untuk mencapai tujuan pembelajaran. (Sari, 2017).

Khusus menyangkut pembelajaran di kelas, sampai saat ini terdapat beberapa model desain pembelajaran yakni ADDIE, ASSURE, dan ARCS. Pada penelitian ini peneliti memutuskan untuk menggunakan desain pembelajaran model ASSURE. Desain pembelajaran ASSURE adalah petunjuk prosedural untuk merencanakan dan menjalankan pembelajaran termasuk media dan teknologi pembelajaran yang akan dipakai (Sundayana, Herman, \& Dahlan, 2017). Model tersebut merujuk kepada analisis kebutuhan ideal untuk suatu kegiatan pembelajaran yang hasilnya diyakini dapat membantu guru mencapai tujuan pembelajaran secara lancar dan efektif. Karena seluruh aktivitas pembelajaran yang diterapkan merupakan hasil analisis yang mendalam yang dituangkan dalam suatu perencanaan yang resmi 
dan selanjutnya diaplikasikan dalam kegiatan pembelajaran (Mohanasundaram, 2018).

Para ahli pendidikan mendefinisikan desain pembelajaran dengan berbagai pendapat. Smith dan Ragan (dalam Pribadi, 2010: 58) menyebutkan bahwa, desain sistem pembelajaran adalah proses sistematik yang dilakukan dengan menerjemahkan prinsip-prinsip belajar dan pembelajaran menjadi rancangan yang dapat diimplementasikan dalam bahan dan aktivitas pembelajaran. Gagne (dalam Pribadi, 2010: 58) menyatakan desain pembelajaran adalah serangkaian sumber belajar dan prosedur yang digunakan untuk memfasilitasi berlangsungnya proses belajar.

Smith dan Ragan's dalam (dalam Putrawangsa, 2018: 21) mengemukakan bahwa, desain pembelajaran itu adalah "the systemic and reflective process of translating principles of learning and instruction into plans for instructional materials, activities, information resources, and evaluation". Dalam definisi ini, Smith dan Ragan's menegaskan bahwa desain pembelajaran adalah proses yang sistematis dan reflektif dalam menerjemahkan prinsip-prinsip belajar dan pembelajaran ke dalam bentuk suatu perencanaan yang digunakan sebagai materi pembelajaran, kegiatan pembelajaran, sumber belajar, dan evaluasi pembelajaran.

Desain pembelajaran sebagai proses pengembangan pengajaran secara sistematik yang digunakan secara khusus teori-teori pembelajaran unuk menjamin kualitas pembelajaran. Pernyataan tersebut mengandung arti bahwa penyusunan perencanaan pembelajaran harus sesuai dengan konsep pendidikan dan pembelajaran yang dianut dalam kurikulum yang digunakan (Klement, 2014).

Model pengembangan ASSURE merupakan singkatan dari komponen atau langkah penting yang terdapat di dalamnya yaitu: menganalisis karakteristik siswa (analyze learner characteristics); menetapkan tujuan pembelajaran (state performance objectives); memilih metode, media, dan bahan pelajaran (select methods, media and materials); memanfaatkan media dan bahan pelajaran (utilitize materials); mengaktifkan keterlibatan siswa (requires learner participation); evaluasi dan revisi (evaluation and revisi) (Heinich, Molenda, Russell, \& Smaldino, 2002).

Pembelajaran tematik terpadu merupakan pendekatan pembelajaran yang mengintegrasikan berbagai kompetensi dari berbagai mata pelajaran ke dalam berbagai tema. Pengintegrasian tersebut dilakukan dalam dua hal, yaitu integrasi sikap, keterampilan dan pengetahuan dalam proses pembelajaran dan integrasi berbagai konsep dasar yang berkaitan. Tema merajut makna berbagai konsep dasar sehingga peserta didik tidak belajar konsep dasar secara parsial. Dengan demikian pembelajarannya memberikan makna yang utuh kepada peserta didik seperti tercermin pada berbagai tema yang tersedia. (Sukerti, et al, 2015). Pembelajaran tematik terpadu sering disebut sebagai pembelajaran tematik integratif. Menurut Majid (2014 : 122) menyatakan bahwa pembelajaran tematik terpadu (integritif) merupakan pendekatan pembelajaran yang mengintegrasikan berbagai kompetensi dari berbagai mata pelajaran ke dalam tema. 


\section{METODE}

Penelitian ini dilaksanakan di SD Negeri 16 Gadut. Subjek penelitian adalah peserta didik kelas IV SD Negeri Negeri 16 Gadut tahun pelajaran 2019/2020. Penelitian pengembangan model ASSURE menggunakan VAK. Tahapan pada model ASSURE terdapat enam tahapan yang dilalui yaitu: (a) menganalisis pembelajar (analyze learner), (b) merumuskan standar dan tujuan (state standard and objectives), (c) memilih strategi, teknologi, media dan bahan ajar (select methods, media, and materials), (d) menggunakan teknologi, media dan bahan ajar (utilize methods, media, and materials), (e) mengajak partisipasi siswa (requires learner participation), (f) evaluasi dan revisi (evaluate and revise).

\section{HASIL DAN PEMBAHASAN}

Tahapan model pengembangan ASSURE telah dilalui dengan hasil produk berupa Rencana Pelaksanaan Pembelajaran (RPP). Proses pengembangan RPP berpedoman pada model pengembangan ASSURE diawali dengan melakukan (a) menganalisis pembelajar (analyze learner). Pada tahap ini yang dilakukan dilakukan dengan cara menganalisis objek. Objek yang akan dianalisis yaitu berdasarkan hasil dari literatur. Objek yang akan dianalisis dari literatur yaitu berupa buku, hasil penelitian, journal dan literatur lainnya, (b) merumuskan standar dan tujuan (state standard and objectives). Tujuan pembelajaran merupakan rumusan atau pernyataan yang mendeskripsikan tentang pengetahuan, keterampilan, dan sikap yang diperoleh siswa setelah menempuh proses pembelajaran, (c) memilih strategi, teknologi, media dan bahan ajar (select methods, media, and materials). Pemilihan metode, media, dan bahan ajar yang tepat akan mampu mengoptimalkan hasil belajar siswa dan membantu siswa mencapai kompetensi atau tujuan pembelajaran. (d) menggunakan teknologi, media dan bahan ajar (utilize methods, media, and materials). Pada tahap ini yang dilakukan pertama adalah pencermatan umum terhadap teknologi, media, dan materi yang digunakan. Kedua, penyiapan teknologi, media, dan materi yang digunakan, (e) mengajak partisipasi siswa (requires learner participation). Pada tahap ini pemberian contoh, media video, latihan merupakan cara melibatkan aktivitas mental siswa dengan materi yang sedang dipelajari, (f) evaluasi dan revisi (evaluate and revise). Evaluasi yang dilakukan berupa evaluasi formatif dan sumatif.

Validasi desain pembelajaran dilakukan validasi isi/konten untuk mengetahui tingkat validitas desain pembelajaran. Hasil validasi pakar ini berupa koreksi, kritik, dan saran yang nantinya peneliti gunakan sebagai dasar untuk melakukan revisi dan penyempurnaan terhadap desain pembelajaran. Instrumen yang disusun meliputi lembar validasi RPP, lembar pengamatan keterlaksanaan RPP, angket respon peserta didik, angket respon pendidik, lembar observasi aktivitas belajar.

Kepraktisan desain pembelajaran yang dikembangkan diukur dari keterlaksanaan RPP dalam pembelajaran yang dilakukan di kelas. Data mengenai kepraktisan RPP yang dikembangkan, diperoleh dari hasil pengamatan keterlaksanaan RPP, angket respon peserta didik terhadap RPP 
dan angket respon pendidik. Dalam lembar pengamatan keterlaksanaan RPP, pendapat pengamat dikategorikan menjadi empat yaitu sangat praktis (skor 4), praktis (skor 3), kurang praktis (skor 2), dan tidak praktis (skor 1).

Sedangkan dalam angket respon peserta didik dan angket respon pendidik, pendapat peserta didik maupun pendidik dikategorikan menjadi empat yaitu sangat setuju (skor 4), setuju (skor 3), tidak setuju (skor 2), dan sangat tidak setuju (skor 1). Efektivitas desain pembelajaran diukur berdasarkan ketercapain tujuan pembelajaran dengan menggunakan perangkat pembelajaran yang dikembangkan. Aspek keefektifan dilihat dari: 1) aktivitas peserta didik; 2) sikap; 3) pengetahuan peserta didik yang diharapkan melampaui KBM; 4) keterampilan peserta didik. Untuk mengukur aktivitas belajar, menggunakan lembar observasi aktivitas belajar. Pada lembar observasi aktivitas belajar dikategorikan menjadi empat, yaitu sangat baik (skor 4), baik (skor 3), kurang baik (skor 2), dan sangat kurang baik (skor $1)$.

Hasil validasi dan saran-saran perbaikan yang diberikan validator digunakan untuk melakukan revisi RPP. Setelah RPP direvisi dilanjutkan dengan validasi kembali dengan menggunakan lembar uji validasi. Berikut diuraikan hasil validasi RPP melalui desain pembelajaran model ASSURE pada tema 9 kelas IV Sekolah Dasar.

Aspek penilaian RPP meliputi identitas, perumusan tujuan pembelajaran, pemilihaan materi pembelajaran, metode, dan langkah-langkah pembelajaran dengan menggunakan model pembelajaran VAK. Secara ringkas hasil validasi RPP oleh validator dapat dilihat pada tabel berikut.

Tabel 1. Hasil Validasi RPP pada Tema 9 kelas IV SD

\begin{tabular}{|l|l|l|l|}
\hline No & Aspek penilaian & $\begin{array}{l}\text { Rata-rata } \\
\text { validitas }\end{array}$ & Kategori \\
\hline 1. & Identitas & 4 & $\begin{array}{l}\text { Sangat } \\
\text { valid }\end{array}$ \\
\hline 2. & $\begin{array}{l}\text { Perumusan } \\
\text { Indikator }\end{array}$ & 3.75 & $\begin{array}{l}\text { Sangat } \\
\text { valid }\end{array}$ \\
\hline 3. & $\begin{array}{l}\text { Perumusan } \\
\text { tujuan } \\
\text { pembelajaran }\end{array}$ & 3.8 & $\begin{array}{l}\text { Sangat } \\
\text { valid }\end{array}$ \\
\hline 4. & $\begin{array}{l}\text { Pemilihan } \\
\text { materi ajar }\end{array}$ & 4 & $\begin{array}{l}\text { Sangat } \\
\text { valid }\end{array}$ \\
\hline 5. & $\begin{array}{l}\text { Pemilihan } \\
\text { sumber dan } \\
\text { media } \\
\text { pembelajaran }\end{array}$ & 4 & $\begin{array}{l}\text { Sangat } \\
\text { valid }\end{array}$ \\
\hline 6. & $\begin{array}{l}\text { Penyusunan } \\
\text { kegiatan } \\
\text { pembelajaran }\end{array}$ & 3.85 & $\begin{array}{l}\text { Sangat } \\
\text { valid }\end{array}$ \\
\hline 7. & $\begin{array}{l}\text { Penilaian } \\
\text { Rata-rata }\end{array}$ & 3.75 & $\begin{array}{l}\text { Sangat } \\
\text { valid }\end{array}$ \\
\hline & $\begin{array}{l}\text { Sangat } \\
\text { valid }\end{array}$ \\
\hline
\end{tabular}

Berdasarkan rata-rata hasil validasi dari validator tentang rencana pelaksanaan pembelajaran maka didapat kategori hasil validasi sangat valid berada pada 3,87 persentase $96,75 \%$ dengan konversi A dengan nilai 85,01\% - 100\%. RPP sudah dapat digunakan sebagai panduan pelaksanaan proses pembelajaran.

Praktikalitas RPP diketahui dari keterlaksanaan RPP, angket respon pendidik dan angket respon peserta didik. Keterlaksanaan RPP dilihat dari observasi pelaksanaan pembelajaran berdasarkan lembar observasi keterlaksanaan RPP dilakukan oleh observer. Hasil keterlaksanaan RPP dapat dilihat pada tabel 2 berikut. 
Tabel 2. Hasil Uji Praktikalitas Keterlaksanaan RPP pada Tema 9 kelas IV SD

\begin{tabular}{|l|l|l|l|}
\hline No & $\begin{array}{l}\text { Aspek } \\
\text { penilaian }\end{array}$ & $\begin{array}{l}\text { Rata-rata } \\
\text { validitas }\end{array}$ & Kategori \\
\hline 1. & Pendahuluan & 3,8 & Sangat praktis \\
\hline 2. & $\begin{array}{l}\text { Kegiatan } \\
\text { inti }\end{array}$ & 3,9 & Sangat praktis \\
\hline 3. & Penutup & 3,8 & Sangat praktis \\
\hline \multicolumn{2}{|l|}{ Rata-rata } & 3,83 \\
\hline \multicolumn{2}{|l}{ Persentase } & 95,83 & \\
\hline
\end{tabular}

Berdasarkan tabel 2 di atas dapat dilihat bahwa keterlaksanaan RPP yang dilakukan melalui observasi meliputi aspek penilaian kegiatan pendahuluan, kegitan inti, dan penutup dengan rata-rata 3,83 dengan rata-rata persentase $95,83 \%$, yang menunjukkan bahwa kriteria keterlaksanaan RPP secara keseluruhan sangat praktis

Angket repon guru diberikan untuk mengetahui pendapat guru terhadap RPP yang dikembangkan. Angket ini diisi oleh dua orang guru kelas. Analisis hasil pengolahan data yang diperoleh masing-masing angket respon guru terhadap praktikalitas RPP dapat dilihat pada tabel 3 berikut.

Tabel 3. Hasil Angket respon guru terhadap RPP

\begin{tabular}{|c|l|l|l|}
\hline No & Aspek penilaian & $\begin{array}{l}\text { Rata-rata } \\
\text { validitas }\end{array}$ & Kategori \\
\hline 1. & $\begin{array}{l}\text { Kepraktisan } \\
\text { Penyajian }\end{array}$ & 4 & $\begin{array}{l}\text { Sangat } \\
\text { praktis }\end{array}$ \\
\hline 2. & $\begin{array}{l}\text { Kepraktisan } \\
\text { Penggunaan }\end{array}$ & 4 & $\begin{array}{l}\text { Sangat } \\
\text { praktis }\end{array}$ \\
\hline 3. & Waktu & 3 & $\begin{array}{l}\text { Sangat } \\
\text { praktis }\end{array}$ \\
\hline & Rata-rata & 3,67 & $\begin{array}{l}\text { Sangat } \\
\text { praktis }\end{array}$ \\
\hline & presentase & $91,67 \%$ & \\
\hline
\end{tabular}

Berdasarkan tabel 3 di atas dapat dilihat bahwa angket respon guru terhadap RPP yang telah dikembangkan telah memiliki tingkat kepraktisan dengan kategori praktis, rata-rata 3,67 dengan presentase $91,67 \%$. Dari hasil repon guru ini diketahui bahwa RPP yang dikembangkan dapat membantu guru dalam pembelajaran.

Angket respon peserta didik diberikan kepada seluruh peserta didik kelas IV sebagai subjek penelitian. Analisis hasil pengolahan data yang diperoleh masing-masing angket respon peserta didik terhadap praktikalitas RPP. Adapun hasil respon peserta didik berada pada kategori sangat baik dengan rata-rata persentase $86,09 \%$. Analisis data keefektifan diperoleh melalui aktifitas peserta didik dan hasil belajar peserta didik, dapat diuraikan di bawah ini:

Hasil pengamatan aktivitas belajar peserta didik selama kegiatan pembelajaran dilakukan oleh dua orang observer, untuk pembelajaran 1 dan 2 . Pada pembelajaran 1 rata - rata aktivitas belajar peserta didik di kegiatan pendahuluan berada pada angka $82 \%$, pada pembelajaran 2 berada pada angka 84\%. Pada aktivitas kegiatan inti Pembelajaran 1 berada pada angka 93\%, pada Pembelajaran 2 sebanyak 89,5\%. Persentase mengalami penurunan pada kegiatan inti dari $93 \%$ menjadi $89,5 \%$. Untuk aktivitas kegiatan penutup dalam proses pembelajaran relatif stabil. Pada Pembelajaran 1 rata - rata aktivitas peserta didik berada pada angka $95 \%$, sedangkan pembelajaran 2 pada angka $96 \%$.

Tes hasil belajar peserta didik setelah menggunakan desain pembelajaran model ASSURE menggunakan VAK pada pembelajaran 
tematik terpadu tema 9 kelas IV telah mencapai KBM dengan nilai rata-rata peserta didik 80,7 berdasarkan KBM yang telah ditetapkan di SD Negeri 16 Gadut yaitu 70, dari 11 peserta didik telah mencapai KBM sebanyak 9 peserta didik, yang artinya pembelajaran sudah efektif digunakan.

\section{KESIMPULAN}

Dapat disimpulkan bahwa model desain pembelajaran ASSURE menggunakan VAK memenuhi aspek kevalidan, kepraktisan dan kefektifian baik ditinjau dari respon pendidik dan peserta didik.

\section{DAFTAR PUSTAKA}

Alimuddin. (2014). Penilaian dalam kurikulum 2013. In Seminar NAsional Pendidikan Karakter. https://doi.org/10.1038/jes.2014.32

Heinich, R., Molenda, M., Russell, J., \& Smaldino, S. (2002). The ASSURE Model. In Instructional Media and Technologies for Learning.

Joseph, W. (2017). Implementasi Kurikulum Tingkat Satuan Pendidikan (KTSP): Dalam Pembelajaran Seni Musik di SMA CitiSchool Semarang. Resital: Jurnal Seni Pertunjukan, 25(1), 3-6.

Karli, H. (2016). Penerapan Pembelajaran Tematik SD Di Indonesia. EduHumaniora| Jurnal Pendidikan Dasar Kampus Cibiru. https://doi.org/10.17509/eh.v2i1.2752

Kemendikbud. (2013). Implementasi Kurikulum. Permendikbud. https://doi.org/10.1017/CBO9781107415324. 004

Kemendikbud. (2014). Modul pembelajaran 2013. Kewirausahaan.

Klement, M. (2014). How do my Students Study? An Analysis of Students' of Educational Disciplines Favorite Learning Styles According to VARK Classification. Procedia - Social and Behavioral Sciences, 132, 384390. https://doi.org/10.1016/j.sbspro.2014.04.326

Marta, H., Fitria, Y., Hadiyanto, H., \& Zikri, A. (2020). Penerapan Pendekatan Contextual Teaching and Learning Pada Pembelajaran Ipa Untuk Meningkatkan Hasil Belajar Dan Motivasi Belajar Siswa Sekolah Dasar. Jurnal Basicedu, 4(1), 149-157. https://doi.org/10.31004/basicedu.v4i1.334

Mohanasundaram, K. (2018). Curriculum Design and Development. Journal of Applied and Advanced Research. https://doi.org/10.21839/jaar.2018.v3is1.156

Noviati, A., Bentri, A., \& Zikri, A. (2020). Pengaruh Penerapan Model Problem Based Learning (Pbl) Terhadap Aktivitas Dan Hasil Belajar Siswa Pada Pembelajaran Tematik Terpadu Di Kelas V Sekolah Dasar. Jurnal Basicedu, 3(2), 524-532. https://doi.org/10.31004/basicedu.v4i3.416

Permendikbud. (2013). Peraturan Pendidikan dan kebudayaan Republik Indonesia. Peraturan Menteri Pendidikan dan Kebedayaan.

Sundayana, R., Herman, T., \& Dahlan, J. A. (2017). Using ASSURE learning design to develop students, mathematical communication ability. WIETE, 15(3), 245249.

Trianto. (2014). Model Pembelajaran Terpadu. Konsep Strategi Dan Implementasinya Dalam KTSP. 